\title{
Master Narratives of Ukrainian Political Culture
}

\author{
Charles McGrath
}

\author{
Doctor of Philosophy (student), Lecturer, Political Science Department, \\ Taras Shevchenko National University of Kyiv \\ (Monroe, Louisiana, United States) \\ E-mail: charlesm365@gmail.com \\ ORCID: 0000-0003-1082-6466
}

As fighting between Russian backed rebels and government forces is taking place in eastern Ukraine, it is all the more apparent the existing political divide that exists in the country. The complex history of being subjugated by surrounding countries and major resettlements of Ukrainians is testing the country in a major way. Historically, emphasis on understanding the Soviet Union was focused on the Soviet perspective - the Soviet narratives, and most recently on reemerging Russia. As a result, little attention is placed on Ukraine's history.

In order to understand the Ukrainian identity, it's necessary to know the narratives that encompass Ukraine's history. As freedom and liberty exemplifies American identity and ideology, the history of Ukraine also contains a system of stories that support Ukrainian culture. This paper, the first chapter of my dissertation, details the sources I've used to develop my methodology for understanding and analyzing narratives. As I began my research I soon realized the complexity of narratives leading me to explore the elements contained in narratives such as story, plot, character, archetypes, and the Hero's Journey or Monomyth. I will explain how I understand the meaning of narrative and master narrative, supported by relevant sources, and conclude with the methodology I will use for analysis of the master narratives that envelope the major historical events of Ukraine.

Keywords: Ukraine, Political Science, History, Narrative, Master Narrative, Russia, National Identity

Received January 16, 2018; accepted March 13, 2018

Future Human Image, Volume 9, 2018:

DOI: $10.29202 / \mathrm{fhi} / 9 / 7$

\section{Introduction}

Ukraine holds a high significance at this time, especially for the United States, given the recent tension between NATO and Russia. Ukraine stands at the center of recent events in the heart of Europe, such as Euromaidan, the ouster of its president, the annexation of Crimea, the fighting in Eastern Ukraine, and a passenger airliner being shot down. It is crucial to have more Americans with expertise on Ukraine. With this in mind, I have applied to, and been accepted into, the PhD program in Political Science at Taras Shevchenko National University of Kyiv.

(C) McGrath, Charles, 2018 
My project is to investigate the master narratives that are drivers of Ukraine's identity. I will examine the events that make up the master narratives and existing counter narratives. For instance, a Ukrainian master narrative as told in Russian history may run counter to Ukraine's perspective. In researching Ukraine's master narratives, I will also analyze the heroes, symbols, stories, and traditions that represent those narratives. For example, a song honoring martyrs of Euromaidan, a poem about the Great Famine of Ukraine 1932-1933, the life of Taras Shevchenko, and so on.

Knowledge of the master narratives that affect the collective identity or identities of the Ukrainian people will give US foreign policy makers insight into Ukraine's attitudes, behavior, interpretive paradigms, and potentially future decisions and courses of action. Narrative has in recent years become an increasingly important focus of research in the areas of international relations, security, conflict, and warfare. It is widely accepted that narratives are a formative element of collective identities and a critical factor in shaping attitudes and motivating behavior. Every culture or group also has master narratives that underlie members' interpretations of events, shape perceptions of the behaviors and motivations of other actors, and influence decision-making. Studies such as Master Narratives of Islamist Extremism by Jeffrey Halverson et al, contributed significantly to our understanding of the dynamics of conflict in the Middle East and to understanding the behavior and motivations of actors. This research paper takes its cue broadly from that work. I will examine relevant literature on Ukrainian history, narratives, speeches and symbols that have shaped Ukrainian collective memory and identity that appear to influence interpretations of current events and perceptions of the motivations of the various actors involved (that in effect underlie the "stories" people tell about what they see happening).

Ukrainian political history encompasses the leaders and rebels that made a lasting impact on Ukraine's identity. For instance, Vladimir the Great is remembered for accepting Orthodox Christianity and introduced it as the official religion of medieval Ukraine. Or, Ivan Mazepa, who lead Ukrainian's fight for independence against the Russian Empire during the Battle of Poltava. Or, controversial figure Stepan Bandera, a leader of the Ukrainian nationalist movement, who initially sided with Germany during the second world war as the country fought for its independence. The aforementioned events are part of the master narratives that support Ukrainian identity.

\section{Definition of Narratives}

In order to understand narrative's and master narratives it is necessary to analyze the various definitions of them, beginning with narrative. According to Merriam-Webster, narrative is "something that is narrated: story, account." For example, "He is writing a detailed narrative of his life on the island." Furthermore, to narrate something is "to tell (a story) in detail (MerriamWebster, 2017). The Oxford dictionary defines narrative with slightly greater detail. Such as,

a spoken or written account of connected events; a story. For example, a gripping narrative. Or, the narrated part of a literary work, as distinct from dialogue; the practice or art of telling stories; a representation of a particular situation or process in such a way as to reflect or conform to an overarching set of aims or values. (English Oxford Living Dictionaries, 2017) 
Thus, we understand that to narrate is to tell a story. Story and plot is sometimes used interchangeably. Yet, there is a distinct difference. According to Aristotle, of the six elements of tragedy (plot, character, diction, thought, spectacle and song), plot is most important. It must have a beginning, middle and end, and the events of the plot should have causality, meaning something happens, which naturally causes something else happening - cause and effect.

Aristotle placed plot above character - though character is a close second in importance. "Now character determines men's qualities, but it is by their actions that they are happy or the reverse" (Aristotle, VI. 9-14, 1922). However, $19^{\text {th }}$ century English critic Leslie Stephen placed character above plot in importance, "The great object of narrative action was the revelation of character." (Abbott, 2002: 124). Henry James offered a third variant, as he considered plot and character to be a blend of both — which is the perspective I will write from. "Henry James, argued that no one could learn the art of novel writing by learning first to make characters and second to devise the action." (Abbott, 2002: 124) The purpose of a story is to teach and though it must have interesting, complex and developed characters, it is their actions, or reaction to actions that define character. Moreover, in analyzing the master narratives of Ukraine, the events and actions that were taken by historic figures, and how those events are retold will take precedence.

Returning to the distinction between plot and story, Edward Forster, who's definition is used in A Dictionary of Narratology by Gerald Prince, explained the difference between the two. He said,

We have defined story as a narrative of events arranged in their time sequence. A plot is also a narrative of events, the emphasis falling on causality. "The king died and then the queen died," is a story. "The king died, and then the queen died of grief" is a plot. The time sequence is preserved, but the sense of causality overshadows it. (Forster, 1927: 130)

In other words, a story is about the main events that take place. Whereas, the plot is how the story is told. Consider the difference between how the following story and plot are told:

This is a 'story' about a man who has been living his life avoiding serious commitment with women. Instead of lasting and meaningful relationships, he has short flings and always ends the relationship before they can get serious. He eventually meets a woman, and their flings become more and more passionate until he realizes that he's fallen in love. He decides to express his love to her only to find out she's married and she never had any intention of settling down with him. Heartbroken, he decides to become a better man and not run away from love in the future.

This story could be told in a number of different ways depending on the 'plot'. One possibility could be told as follows:

Jason, a business consultant in his thirties, meets Stephanie, a beautiful girl in her late twenties who works as an executive assistant. He takes her out to dinner using his usual charm, intent on seducing her but wanting nothing more. He finds her to be sarcastic, opinionated and annoying, but is still intrigued with her. They meet again at a museum and while looking at a Monet painting she explains to him why she loves impressionism which he finds boring. Yet, he's impressed with how smart she is, and captivated with her feistiness and strong personality. One night they sleep together at her apartment and shortly after their rendezvous become more and more passionate. Jason tells himself that he will end their relationship eventually but continues seeing her. After a few months, she tells him that she's moving to another city for 
work. He acts nonchalant and wishes her the best. After a few weeks, he realizes that he misses her deeply and cannot stop thinking of her. He thinks about her when he's at work, when he's out with his friends and especially when he's alone. Sitting in a coffee shop, Jason reminisces about their first dinner together. How she annoyed him with her sarcastic remarks and the way she laughed as they argued. He thinks about their date at the museum and how elegant she looked. And about the way she looked at him, listening so attentively with such empathy as he told her how his father died, and how peaceful she looked when she was sleeping next to him. At that moment, he realizes he's in love and rushes home to call her and express his love for her. On the phone, she confesses that she's married and never thought their relationship would get so serious. Irrationally, he pleads with her to leave her husband so that they can have a life together, but she refuses. Heartbroken he realizes what love is and that he was wrong to avoid it for so long. He decides he will be a better man for the next woman he meets. As you can see the plot describes how the events take place rather than merely what the story is about.

As there are repeated story forms that we are all familiar with such as the love story or the story of a hero overcoming evil and saving his people, there are also repeated characters that we call archetypes. Archetype's are "the original pattern or model of which all things of the same type are representations or copies." (Merriam-Webster , 2017) Archetypes according to Carl Yung are standard characters that all people seem to recognize and are loaded with emotion. As if the archetypes are part of a 'collective unconscious' that we are born with (Yung, 1988: 78). "Archetypes create myths, religions, and philosophies that influence and characterize whole nations and epochs of history" (Yung, 1988: 79). In addition, Joseph Campbell who was heavily influenced by Yung's work, wrote a great deal about ancient mythology and the common archetypes contained in those myths and fairy tales. In the Hero with a Thousand Faces, he wrote about the prevailing Hero's Journey or Monomyth, which has been taught through a great number of myths throughout history - the myths teaching the different stages of a hero's journey. These stories contain the major archetypes and can be seen in such movies such as Star Wars, the Gladiator, Braveheart, and so forth. In Star Wars, Luke Skywalker is the Hero archetype, Darth Vader the Shadow or Villain archetype, Yoda the Wise Old Man, Obi-Wan Kenobi the father figure, and so on. Moreover, portions of the hero's journey can be found in master narratives such as the 'freedom and liberty' master narrative of America, as told through the life, i.e. 'Hero's Journey', of such people as Davey Crockett, George Washington and Abraham Lincoln. Consider the difference between labeling someone a terrorist or calling him a freedom fighter — utilizing a different frame. Thus, the narrator has reframed the archetype from that being of a villain to a hero. In an interview during the First Gulf War in 1990 - 1991, Usama Bin Laden repeatedly referred to the West as an alliance of 'crusaders' and 'Jewish-Zionist's', "The international crusaders and the Jewish Zionist alliance headed by America, Britain and Israel.” (Laden, 2001) Hence, he evokes the intended audience, those with sympathetic views, to identify the West with two well-known archetypes. More recently the protestors in Ukraine's 2014 Maidan Revolution (Revolution of Dignity), have been labeled as Fascist's, neo-Nazis and nationalists by Russian and even some western media. Therefore, using an archetype to label someone or some group for political purposes can immediately induce a narrative or even master narrative.

Next, I will define narrative and then master narrative. H. Porter Abbott gives the following explanation, "narrative is the representation of events, consisting of story and narrative discourse, story is an event or sequence of events (the action), and narrative discourse is those events as represented." (Abbott 2002: 16) That is to say, events happen which make a story 
and how those events are retold is a narrative. For example, Stepan Bandera, a fascist and Nazi collaborator was killed by KGB agents. The previous sentence uses the fascist and Nazi archetypes to label Bandera. Compare the following sentence: Stepan Bandera, a political activist, who cooperated with Germany was assassinated by Stalin's assassins. Thus, the story (event) has been narrated with a new frame utilizing the despot or tyrant archetype (Stalin), and the audience may identify Stephan Bandera with the victim, hero, or martyr archetypes. Keep in mind that characters in a story may have more than one archetype and "all archetypes are tied to story forms, but not all characters in stories are necessarily archetypes." (Halverson, et al., 2011: 21)

I once asked an eleven-year-old English student what are stories for? And he quickly answered, "They teach us how to live." I cannot think of a better and more succinct answer. I might add that narratives help us make moral decisions. Abbott explains they help us make up our minds about things. Especially when we are faced with difficult moral problems. "In almost every one of these narratives, the central figure is torn by a moral dilemma and, as the narrative proceeds, is pulled back and forth between competing moral claims" (Abbott, 2002: 175). There seems to be a predisposition for us to be believe there is a higher power, an all knowing narrator teaching us. Abbott alludes to it as a power who helps us create order out of chaos (Abbott, 2002: 95), while Halverson reaches a similar conclusion that "Narratives not only hang together and make sense of the world. ... they also create expectations for what is likely to happen and what the audience is expected to do about it" (Halverson, et al., 2011: 25).

In addition to helping us make sense of the world, entertaining us, teaching us how to deal with difficult moral dilemmas, or a combination of all three — narratives serve another important function. Which is, to solve some kind of conflict. For example, a set of stories told about unarmed black men in the U.S. who have been shot by police might make up an 'anti-law enforcement narrative', which has the objective of changing police practices. As Halverson stated, the audience understands the conflict and knows what they're expected to do about it. While the previous example was of a current narrative frequently shown on US news sites, other common narratives may tell of stories that originated decades or centuries ago. As Aristotle said, a plot must have a beginning, middle, and end. Likewise, a narrative has an end, or more specifically a desired ending that the audience is anticipating - a man wins the love of a woman, Bruce Willis kills the bad guys, American Patriots establish a new nation, and so forth. Thus, the audience understands and anticipates the desired outcome - which creates suspense. As every good story has mystery in order to create suspense the same holds true for narratives. As the audience understands the desired outcome and the fact that it hasn't yet been achieved, it creates an emotion that motivates the audience to continue following the narrative and/or taking action. Abbott explains it as the difference between an ending and closure. "... closure does not have to come at the end of a narrative; in fact, it does not have to come at all" (Abbott, 2002: 52). Explaining how the desired outcome not being achieved causes tension and anticipation he says, "If the object is to satisfy this desire which is often the case - it can't be satisfied too quickly, because we seem also to enjoy being in the state of imbalance or tension that precedes closure. In fact, narrative is marked almost everywhere by its lack of closure. Commonly called suspense, this lack is one of the two things that above everything else give narrative its life (Abbott, 2002: 53).

Which brings us to master narratives (also called masterplots). The main difference between a narrative and master narrative is that the master narrative is transhistorical. Halverson 
explains that master narratives contain story forms with the desire to achieve a political or ideological end to a conflict.

Story forms are standard patterns on which stories may be based, defining the typical characters, their actions, and sequences of events in a story. For example, a "rags to riches" story involves a protagonist who goes from poverty to prosperity, only to suffer a setback at the hands of an antagonist, which must be overcome in order to restore his or her success (Halverson, et al., 2011: 20).

Halverson goes on to explain that master narratives are narratives which are deeply fixed in a particular culture which can take decades or longer to develop.

"A narrative is a coherent system of stories that share a common rhetorical desire to resolve a conflict by establishing audience expectations according to the known trajectories of its literary and rhetorical form. A master narrative is a transhistorical narrative that is deeply embedded in a particular culture" (Halverson, et al., 2011: 23-24).

Abbott argues that master narratives, which he calls masterplots, are constantly repeated as they use the conflicts that seem to be "a permanent part of our circumstances as human beings" (Abbott, 2002: 158).

In order to gain a deeper understanding of how narratives are created and affect people, I've found Abbott and Halverson to be the most helpful and applicable for my analysis of the master narratives of Ukraine. Halverson's book analyzes narratives from a political perspective, whereas, Abbott analyzes how narratives work in general storytelling, such as through novels and film. As a result, my understanding of narrative most closely resembles Halverson's. Therefore, I define narrative and master narrative using Halverson's construct: a story is a particular sequence of related events that are situated in the past and recounted for rhetorical/ideological purposes. A narrative is an organized system of stories with a common rhetorical desire to resolve a conflict by establishing audience expectations. For example, the anti-pollution narrative, which is a system of stories that show effects and disasters caused by climate change through news reports, documentaries, and film. A Master Narrative is a transhistorical narrative that is deeply embedded in a particular culture, provides a pattern for social structure, and creates a framework for communication about what people are expected to do in certain situations. For instance, a willingness to fight for and achieve 'Freedom \& Liberty.' The "Freedom \& Liberty" master narrative is supported by stories from the Revolutionary War, such as The Boston Massacre or The Battle of Bunker Hill; stories from the Mexican American War, such as The Battle of the Alamo; and stories from the Second World War, such as Pearl Harbor, Battle of Midway, and so on.

\section{Methodology}

Historiography is concerned with the methods historians use to research and write about history. However, the aim of this paper is not to prove whether the master narratives actually happened as they are represented, but rather to analyze what the primary Ukrainian master narratives are, and to compare the similarities and differences among Russian and Ukrainian historians. 
Thus, the following will serve as my criteria for how I will analyze the source materials. The authors will be identified as to what point of view they wrote from, e.g., Intentionalist, Functionalist, Marxist, and so forth. However, the main focus will be on what are the master narratives, how are they told, what is the call to action, what is the aim, and how the narrative may or may not differ in Ukrainian and Russian and Soviet discourse. My system will consist of the following stages when reading sources:

1) What was the authors point of view at the time. For example, was he writing from a Marxist, political history, or other methodology?

2) What are the similarities or differences in how the stories are narrated? For example, narratives on the Ukrainian Famine (1932-1933) differ among Ukrainian and Russian historians.

3) Is there a reason why the narratives are similar or differ?

The way I have defined story, plot, narrative and master narrative form the basis of my methodology in analyzing the master narratives of Ukraine. As described earlier, Halverson's definition and methodology most closely fits how I understand, and will investigate the master narratives of Ukraine, (and how they may differ in Russia), I will use his criteria for my analysis. They are as follows:

- What are the stories and how are they systematically related?

- What stories make up the narrative?

- How do they relate to one another to create coherence?

- What are the archetypes, and how do they relate to one another?

- What is the trajectory of the story form?

- To what desire(s) of the audience does the narrative appeal?

- What is the end state conveyed by the narrative for satisfaction of the desire?

- What is the narrative path that leads from desire to satisfaction?

- How are the narratives used by speakers to create ideological preferences

for courses of action and expectations for what is to be done?

- What evidence is there that the narrative is deeply embedded within a culture? (Halverson, 2001: 26)

\section{Conclusion}

Thus, the aforementioned comprise my methodology and will be used to study the master narratives of Ukraine from its establishment as Kievan Rus in the $9^{\text {th }}$ century, to its various struggles for more autonomy or independence, and finally achieving lasting independence in 1991. It is the hope that by having established a solid methodology and approach that the reader will be able to easily understand the master narratives which will be explained in future chapters and publications, why the master narratives are meaningful to understanding the Ukrainian identity, and that it will stand up to future criticism.

\section{메] References}

Abbott, H. Porter. The Cambridge Introduction to Narrative. New York: Cambridge University Press, 2002. 
Aristotle. Aristotle's Poetics. (S. Butcher, Ed.) London: Macmillan and Co., Limited. 1922.

Campbell, Joseph. The Hero with a Thousand Faces. Princeton, New Jersey: Princeton University Press. 2004.

English Oxford Living Dictionaries. English Oxford Living Dictionaries. Retrieved from English Oxford Living Dictionaries: https://en.oxforddictionaries.com/definition/ narrative. 2017

Forster, Edward. Aspects of the Novel. New York: Harcourt, Brace, and Company. 1927.

Halverson, Jeffry., Goodall Jr., Harold., \& Corman, Steven. Master Narrative of Islamist Extremism. New York: Palgrave Macmillan. 2011.

Laden, Usama bin. Text: Osama bin Laden's 1998 interview. (U. r. al-Jezeera, Interviewer) The Guardian. 2001.

Merriam-Webster. Merriam-WebsterDictionary. Retrieved from Merriam-Webster:

https://www.merriam-webster.com/dictionary/narrative. 2017.

Prince, Gerald. A Dictionary of Narratology . Lincoln : University of Nebraska Press. 1987.

Yung, Carl. Man and His Symbols. New York: Anchor Press Doubleday. 1988. 